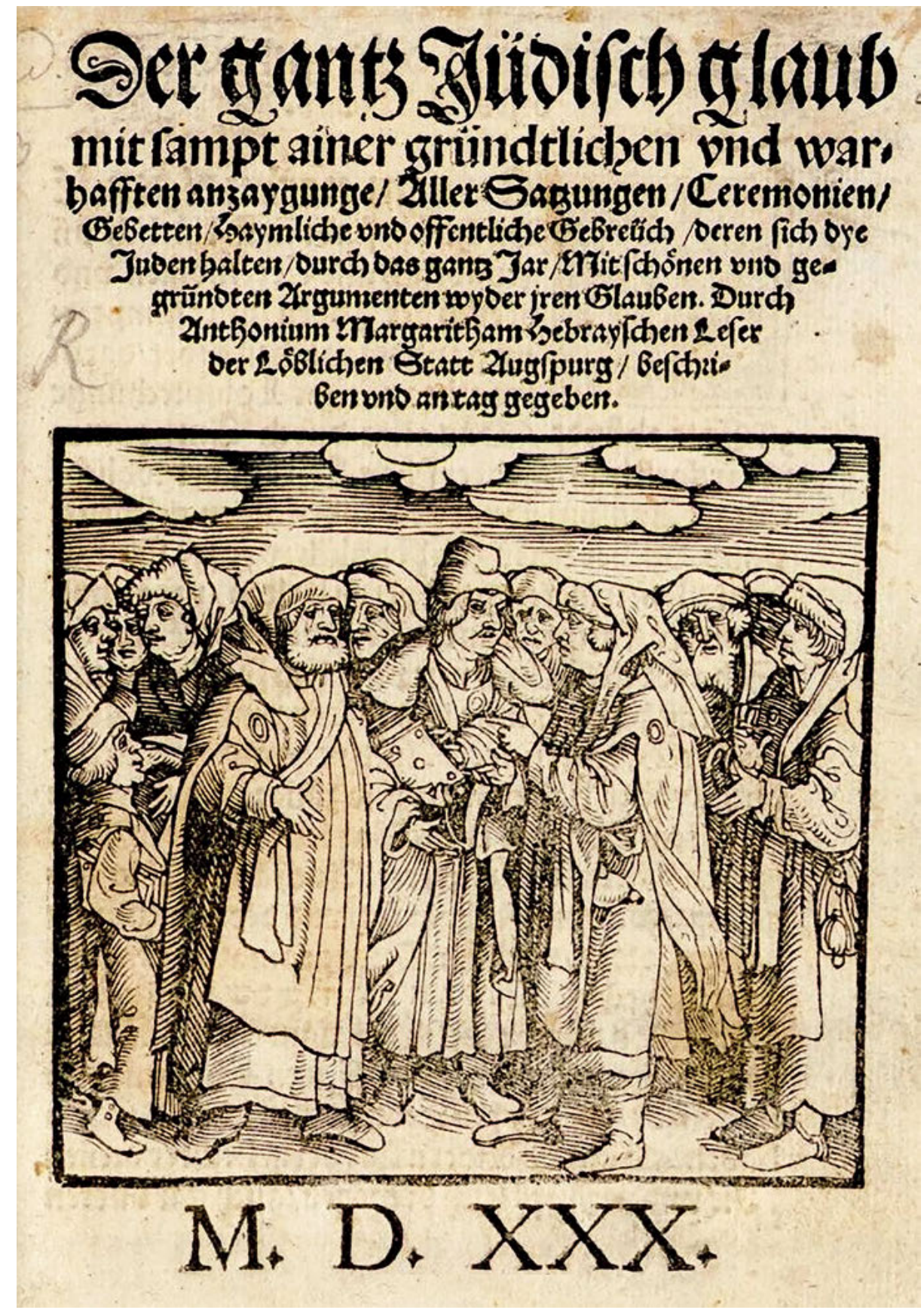

Fig. 4.1: Title page of Anthonius Margaritha, Der gantz Jüdisch glaub (On the entire Jewish faith), Augsburg: H. Steiner, 1530. This text, written by a Jewish convert to Christianity, was greatly influential in German-speaking countries.

Ә Open Access. (C) 2021 Thomas Kaufmann, published by De Gruyter. (c) BY-NC-ND This work is licensed under the Creative Commons Attribution-NonCommercial-NoDerivatives 4.0 International License.

https://doi.org/10.1515/9783110639452-005 


\section{Chapter 4 The Election of Israel? Jews in the Eyes of Early Modern Lutherans}

This article sketches some main trajectories of how the Lutherans conceived of the Jews and their role in salvation history. The basic assumption was that the church had inherited the election of ancient Israel, due to Israel's rejection of Christ as the Messiah. In the beginning, Luther had hopes that the Jews could be converted to the Christian faith and regarded anti-Jewish polemics as "lies." Towards the end of his life, however, Luther constructed them as a counterpart of the evangelical core, the justification by faith alone - contemporary Jews were considered under the heading of "Israel according to flesh.” In spite of some attempts at integrating the Jews in cultural life, many Lutherans in the subsequent generations took part in the effort of alienating the Jews from the true Jerusalem. These discussions were conducted in Scandinavia, too, albeit with a focus on the exemplary function of God's wrath striking faithless Christians as it had once struck the faithless Jews.

As far as I see, one of the dominant convictions concerning Jews and Judaism that Lutheran theologians in the Reformation era and the so-called Confessional Age shared, was that the church has inherited ancient Israel's election. Using the clear terminological distinction between the "true Israel" - which means the Church and the Jews or Jewish people, who stood outside God's election, Lutheran theologians insisted that confessing Jesus Christ as the true Messiah would be the one and only way to salvation, for both Jews and heathen.

Lutheran theology of early modern times denies a prerogative of the Jewish people in the history of salvation. Because "Israel according to the flesh" has rejected God's son and his grace - the Gospel - God himself has rejected them. This is the prevailing position from the "late Luther" up to late Lutheran orthodoxy, represented even in figures like Johann Arndt and Spener's teacher J. C. Dannhauer. ${ }^{1}$

1 Cf. Johannes Wallmann, "Der alte und der neue Bund. Zur Haltung des Pietismus gegenüber den Juden," in Glaubenswelt und Lebenswelten, ed. Hartmut Lehmann, Geschichte des Pietismus 4 (Göttingen: Vandenhoeck \& Ruprecht, 2004); Martin Friedrich, Zwischen Abwehr und Bekehrung. Die Stellung der deutschen evangelischen Theologie zum Judentum im 17. Jahrhundrt. Beiträge zur historischen Theologie 72 (Tübingen: Mohr, 1988).

Thomas Kaufmann, Professor, Georg-August-Universität Göttingen, Germany 
In his very influential tract That Jesus Christ was Born a Jew [Daß Jesus Christus ein geborner Jude sei.] from 1523, Luther had pointed out that the Jews have lost their relation to the faith of their fathers, the prophets, and the patriarchs. Only by converting to Christ and by affirming that several promises in the Ancient Testament - such as Gen 3:15; Gen 22:18; 2 Sam 7:12; Jes 7:14; Gen 49:10; Dan 9:24-27; Hag 2:10 and Zech $8: 23^{2}$ - have been fulfilled in Jesus, a return to "the faith of their fathers, the prophets and patriarchs" 3 will be possible. Although God had acknowledged the Jews more than all other people, their failure of refusing Christ as the Messiah has led to their rejection.

In the beginning of the Reformation process, Luther was quite optimistic about stimulating the Jewish people for Christian faith and attracting them by friendliness and plausible exegetical argumentations. Stereotypes of late medieval Anti-Jewish polemics ${ }^{4}$ like the desecration of the host, ritual murder, and well poisoning have been questioned by Luther and refused as "lies" [lugen teydingen]. ${ }^{5}$ The living together of Christians and Jews and a general permission for Jews to work in different businesses would help to raise interest and open the mind of Jewish people for the Christian creed. In the early 1520s Luther was convinced that it would be possible to win "several"6 Jews for Christianity. He even insisted on a certain genealogical nearness of Jews to Christ because of similar blood. ${ }^{7}$

In his Churchpostill, dated from 1522, Luther had come back to Rom 11:25-26 in a future meaning: "blindness is fallen on parts of the Jewish people until the wealth of the heathen will have entered and the whole Israel will be saved. God may give that this time has come near to us as we hope."8 This interpretation was part of a highly apocalyptic view on his presence which was characteristic for the dynamism of the early phase of the Reformation. Afterwards, the Wittenberg theologian understood Paul's announcement of a conversion of the whole of Israel in Rom 11:25-26 in the tradition of several church fathers like Hieronymus and others in a historical perspective - that is to say, during the centuries between Christ's crucifixion and his second arrival, several Jews have converted to Christianity. But before Christ's parousia, an event that will take place soon, no dramatic conversion of the rest of "Israel according to the flesh" will take place

2 WA 11,316,5ff.; Thomas Kaufmann, Luthers “Judenschriften”. Ein Beitrag zu ihrer historischen Kontextualisierung, 2nd edn. (Tübingen: Mohr, 2013), $17 \mathrm{ff}$.

3 WA 11,315,16.

4 R. Po-Chia Hsia, The Myth of Ritual Murder: Jews and Magic in Reformation Germany (London: Yale University Press, 1988).

5 WA $11,336,24-25$.

6 WA 11,336,23;314,28.

7 WA $11,315,25-27$.

8 WA $10 / 1,289,8-10$. 
at all. In the Lutheran tradition most interpreters followed this "historical" interpretation of Rom 11:25-26. In the late seventeenth century Spener and other Pietists discovered Luther's earliest approach to this text and used it as an argument for their concept of "a hope for better times." 9 There was still time left for reforming the church, and in the end God will convert all Jews to the Christian faith. It was this future interpretation of Rom 11:25-26 that opened the way for historical progress and missionary activities towards Judaism, and ended the conviction that Judgement Day was immediately at hand.

In some vicious writings dealing with Jews as a stubborn and rejected people Luther found his final position towards Judaism in the $1540 \mathrm{~s}^{10}$ The mainstream of Lutheran Orthodoxy followed his view on the Jews, as to use Judaism as a constructed counterpart of the Lutheran faith was quite convenient. Justification by faith alone was explained on the background of Jewish or Roman Catholic religious behaviour. Jews and Papists - as well as Muslims ${ }^{11}$ - try to become "righteous" by doing good works and earning acceptance, while Lutheran Christians trust in God's grace alone.

In some cases Lutheran theologians intervened and attacked political authorities for tolerating Jews in their territories or cities. ${ }^{12}$ While some other Lutheran theologians such as Urbanus Rhegius, Johannes Brenz, or Justus Jonas were following the path of the younger Luther and insisting on the possibility of further Jewish conversions, ${ }^{13}$ strategic attempts for missionizing Jews were unknown in older Lutheranism up to Pietism. The consequences which different Lutherans held in questions of limited toleration of the Jewish people were sometimes contradictory.

Similar to the discourse on Jews and Judaism in the Late Middle Ages, pamphlets written by Jewish converts to Christianity had a strong impact even in the Lutheran tradition. A convert named Antonius Margaritha (c.1490-1542), for instance, wrote a bestseller

9 Cf. Wallmann, "Der alte und der neue Bund. Zur Haltung des Pietismus gegenüber den Juden,” 147f. Martin Jung, Die Württembergische Kirche und die Juden in der Zeit des Pietismus (1675-1780), Studien zu Kirche und Israel 13 (Berlin: Institut Kirche und Judentum, 1992); Udo Arnoldi, Pro Iudaeis. Die Gutachten der halleschen Theologen im 18. Jahrhundert zu Fragen der Judentoleranz, Studien zu Kirche und Israel 14 (Berlin: Institut Kirche und Judentum, 1993).

10 Cf. Thomas Kaufmann, Luther's Jews (Oxford: Oxford University Press, 2017), 94ff. Commenting on Luther's tract On the Jews and their Lies on the background of rabbinic literature cf. Matthias Morgenstern, Martin Luther. Von den Juden und ihren Lügen (Berlin: Berlin University Press, 2016).

11 Cf. Thomas Kaufmann, "Luthers Sicht auf Judentum und Islam," in Der Reformator Martin Luther 2017. Eine wissenschaftliche und gedenkpolitische Bestandsaufnahme, ed. Heinz Schilling (Berlin: de Gruyter, 2014).

12 Cf. e.g. Rotraud Ries, Jüdisches Leben in Niedersachsen im 15. und 16. Jahrhundert. Hannover: Hahn, 1994.

13 Heiko A. Oberman, Wurzeln des Antisemitismus. Christenangst und Judenplage im Zeitalter von Humanismus und Reformation, 2nd edn. (Berlin: Siedler, 1981), 61; Kaufmann, Luthers "Judenschriften". Ein Beitrag zu ihrer historischen Kontextualisierung, (Tübingen: Mohr) 175-77. 
under the title of On the Entire Jewish Faith [Der gantz Jüdisch glaub], which influenced Luther himself and had a long-lasting reception in subsequent generations as well. ${ }^{14}$

While these converts "informed" on what Jews were doing and believing; they also provided "insights" into the "hostility" of the synagogue, pointing out that Jewish prayers tended to blame Christ and his mother, the Virgin Mary. Whatever the Jews did, as Margaritha wanted his readers to believe, it was aimed at damaging Christians' success and weakening their social position.

In Lutheranism - as well as generally in humanism ${ }^{15}$ and in other early modern Christian confessions - the social integration of converts from Judaism did not work well. ${ }^{16}$ Quite the opposite - in many cases people mistrusted the converted Jews and assumed base motives for their religious change. Even if all confessional societies of early modern Europe to a certain extent were suspicious of foreigners, the hostility against Jews or converts from Judaism had deeper roots and stronger consequences. In some cases this hostility was directed not only against the people made responsible for our Lord's death, but also against a nation with "bad instincts" and "evil characters." Within early modern Christianity a pattern of perception of Judaism arose that assigned certain qualities and means of behaviour, especially in economic affairs, within "Jewish blood." Even if the biological concept of race originates only in the nineteenth century, the traces of Antisemitism go back to early modernity; Lutheranism was no less involved in these developments than Catholicism. ${ }^{17}$

14 Cf. Fig. 4.1; Gaby Knoch-Mund, Disputationsliteratur als Instrument antijüdischer Polemik. Leben und Werk des Marcus Lombardus, eines Grenzgängers zwischen Judentum und Christentum im Zeitalter des deutschen Humanismus, Bibliotheca Germanica 33 (Tübingen: Francke, 1997); Peter von der OstenSacken, Martin Luther und die Juden. Neu untersucht anhand von Anton Margarithas "Der gantz Jüdsisch glaub” (1530/1) (Stuttgart: Kohlhammer, 2002); Maria Diemling, "Anthonius Margaritha on the "Whole Jewish Faith": A Sixteenth-Century Convert from Judaism and his Depiction of the Jewish Religion," in Jews, Judaism, and the Reformation in Sixteenth-Century Germany, eds. Dean Bell and Stephen G. Burnett, Studies in Central European Histories 37 (Leiden: Brill, 2006); dealing with Margaritha as an example for "ethnographic" literature cf. Yaacov Deutsch, Judaism in Christian Eyes: Ethnographic Descriptions of Jews and Judaism in Early Modern Europe (Oxford: Oxford University Press, 2012), 229ff.; Yaacov Deutsch et al., Religious Rituals and Ethnographic Knowledge: SixteenthCentury Descriptions of Circumcision, Brill's Studies in Intellectual History 219 (Leiden: Brill, 2013).

15 Thomas Kaufmann, "Einige Beobachtungen zum Judenbild deutscher Humanisten in den ersten beiden Jahrzehnten des 16. Jahrhunderts," in Protestantismus, Antijudaismus, Antisemitismus, eds. Andreas Stegmann, Martin Ohst, and Dorothea Wendenbourg (Tübingen: Mohr Siebeck, 2017).

16 E.g.: Ulman Weiss, "Habet Erbarmen mit meiner armen Jüden-Seele! Judentaufen im kurmainzischen Erfurt," Pietismus und Neuzeit 21 (1995); cf. for Jung, "Die Württembergische Kirche und die Juden", 225ff.

17 Cf. R. Po-Chia Hsia, "Religion and Race: Protestant and Catholic Discourses on Jewish Conversion in the Sixteenth and Seventeenth Centuries," in The Origins of Racism in the West, eds. Miriam EliavFeldon, Benjamin Isaac, and Joseph Siegler (Cambridge: Cambridge University Press, 2009; reprint, 2010). 
In some cases a vibrant apocalyptical worldview expecting the Day of Judgement very soon intensified hatred against Jews in Lutheran theology. If the Lord comes, all those who blame him and reject his majesty have to be suppressed or expelled. Georg Nigrinus (1530-1602), a theologian from Hesse writing a book entitled The Jews' Enemy [Juden Feind], ${ }^{18}$ identified the "synagogue of Sathan" (Rev 2:9) with the Jews. He preferred to call the Jews Thalmudists because they cared for Thalmud and Rabbinic tradition much more than for their father Abraham and the Old Testament. Using the Lutheran sola scriptura-principle, theologians like Nigrinus argued against every Jewish traditionalism other than the Old Testament. Corresponding to Jewish reading of the "impure" Rabbinic sources, the Jewish people for Nigrinus became "impure" even in a genealogical sense: "There are not many left who come from Abraham's seed. Most of the Thalmudists are bastards, mixed between Jews, heathen, Saracens and Christian renegades." ${ }^{19}$ On this line Nigrinus like Luther and some of his followers picked up all sorts of early modern antisemitic stereotypes dealing with the "usurious Jews." 20 The Jews' God is mammon; they serve him and try every way to harm the adherents of the true Lord. Theologians like Nigrinus were convinced that even "baptized Jews" were belonging to a secret confederation of the servants of mammon, that is the devil, who acted permanently to obtain influence over Christians' money and to strengthen the enemies of the true church, for instance the Ottomans or the Papists. For some Lutherans in early modern times Judaism was an integral part of a global conspiracy that aimed at the extermination or the suppression of the true faith.

In Lutheranism impulses to study Rabbinic sources have seemingly been weaker than in Reformed Protestantism; ${ }^{21}$ normally Lutherans did not expect to "learn" anything from Jewish scholarship. Because of the stubbornness of the Jewish people, all their actions were suspected to have an anti-Christian impact. If Jews had to be tolerated because of the financial interests of the political elites, they should be kept in isolated

18 Georg Nigrinus, “Jüden Feind. Von den Edlen Früchten der Thalmudischen Jüden/ So jetziger zeit in Teutschelande wonen . . .," (1570); further "information” on Nigrinus in: Thomas Kaufmann, "Die theologische Bewertung des Judentums im Protestantismus des späteren 16. Jahrhunderts (1530-1600),” in Konfession und Kultur. Lutherischer Protestantismus in der zweiten Hälfte des Reformationsjahrhunderts (Tübingen: Mohr Siebeck, 2006), 146.

19 Cf. Kaufmann, "Die theologische Bewertung des Judentums im Protestantismus,” 148.

20 Cf. R. Po-Chia Hsia, "The Usurious Jew: Economic Structure and Religious Representation in an Anti-Semitic Discourse," in In and Out of the Ghetto: Jewish-Gentile Relations in Late Medieval and Early Modern Germany, eds. R. Po-Chia Hsia and Hartmut Lehmann (Cambridge: Cambridge University Press, 1991).

21 Cf. e.g. Stephen Burnett, From Christian Hebraism to Jewish Studies: Johannes Buxdorf (1564-1629) and Hebrew Learning in the Seventeenth Century, Studies in the History of Christian Thought 68 (Leiden: Brill, 1996); Alfred Bodenheimer, ed., Sebastian Münster, Der Messias-Dialog. Der hebräische Text von 1539 in deutscher Übersetzung (Basel: Schwabe, 2017). 


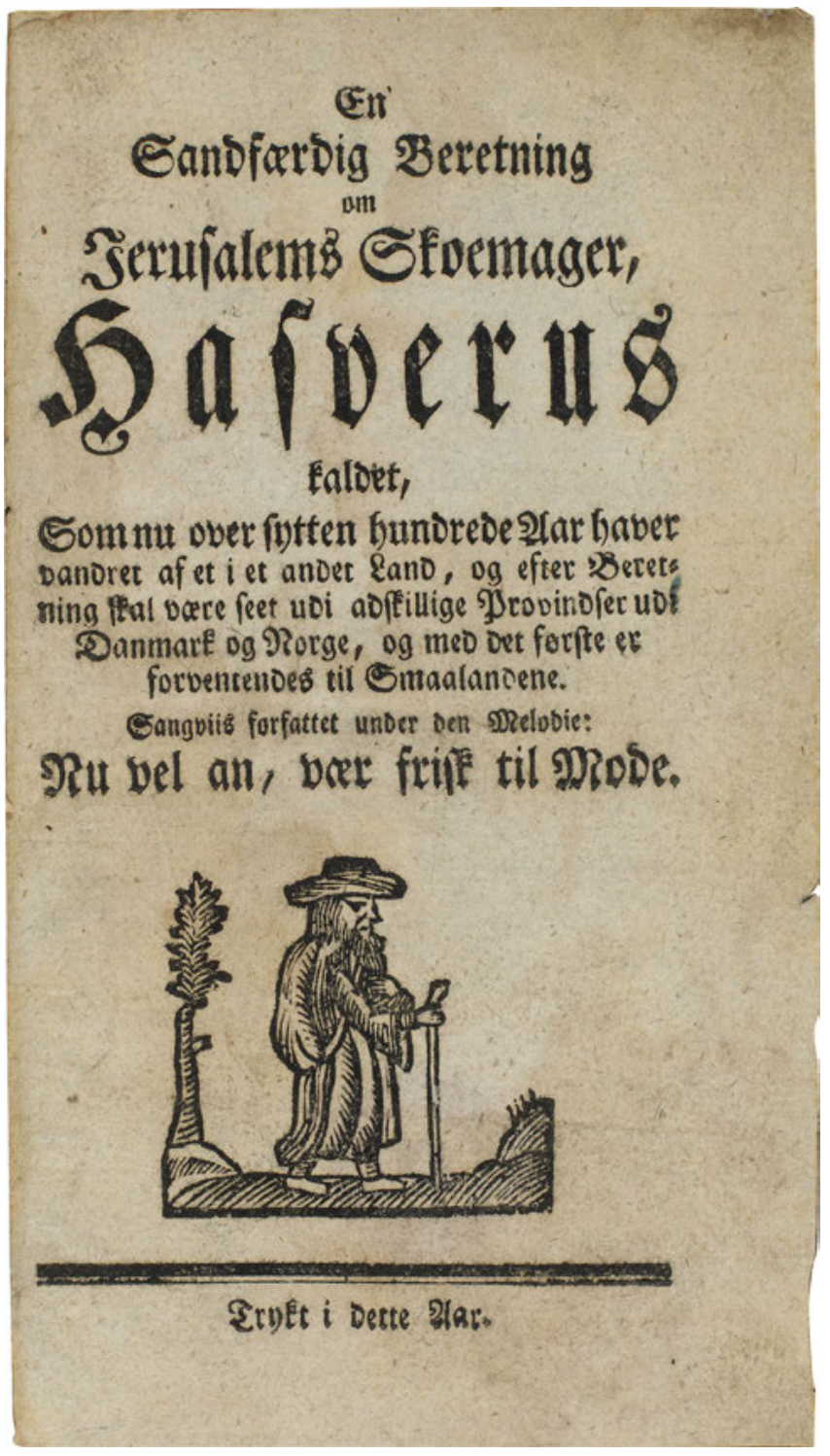

Fig. 4.2: Ahasver. Title page from a Danish popular song from 1705: En sandferdig Beretning om Jerusalems Skoemager, Haferus kaldet, som nu over sytten hundrede Aar haver vandret af et $i$ et andet Land, og efter Beretning skal være seet udi adskillige Provinzer udi Danmark og Norge, og med det første er forventendes til SmaaLandene (A true account of the shoemaker of Jerusalem, called Haferus, who has wandered about in all lands for seventeen hundred years, and according to witnesses is seen in several provinces of Denmark and Norway, and is soon expected to Smaa-Landene (Eastern Norway)).

spheres. In many cases visible sufferings of Jewish people have been used by Lutheran theologians as an argument that they stood under God's wrath. Since the beginnings of the Christian era, Jewish people had lost their state, had been driven out of their country and exiled all over the world, and in many cases had been victims of persecutions and intolerance. Following a tradition of anti-Jewish literature inherited from Antiquity 
and the Middle Ages, ${ }^{22}$ Lutheran theologians used all kinds of mishaps, setbacks, and strokes of fate suffered by the Jews as proof for their divine rejection. In the literary figure of Ahasver (Fig. 4.2), the Jew wandering through the centuries who had been a witness of Christ's crucifixion and was condemned to restlessness, a personification of Jewish blame, ${ }^{23}$ Lutheranism found a specific expression of its deeply rooted uneasiness with Judaism. If Jews did not suffer visibly, the Lutherans' election might be called into question.

22 Cf. Heinz Schreckenberg, Die christlichen Adversus-Judaeos-Texte und ihr literarisches und historisches Umfeld (1.-11. Jahrhundert) (Frankfurt am Main: Peter Lang, 1982); Die christlichen AdversusJudaeos-Texte und ihr literarisches und historisches Umfeld (11.-13. Jahrhundert), 2nd edn. (Frankfurt am Main: Peter Lang, 1991); Die christlichen Adversus-Judaeos-Texte und ihr literarisches und historisches Umfeld (13.-20. Jahrhundert) (Frankfurt am Main: Peter Lang, 1994).

23 Galit Hasan-Rokem, “Art. Ahasver,” in Enzyklopädie jüdischer Geschichte und Kultur, ed. Dan Diner (Stuttgart: Metzler, 2011); Mona Körte and Robert Stockhammer, eds., Ahasvers Spur. Dichtungen und Dokumente vom "Ewigen Juden" (Leipzig: Reclam, 1995); Aaron Schaffer, "The Ahasver-Volksbuch of 1602 [Printed in Bautzen]," in The Wandering Jew: Essays in the Interpretation of a Christian Legend, eds. Galit Hasan-Rokem and Alan Dundes (Bloomington: Indiana University Press, 1986); cf. Kaufmann, "Die theologische Bewertung des Judentums,” 151ff. 


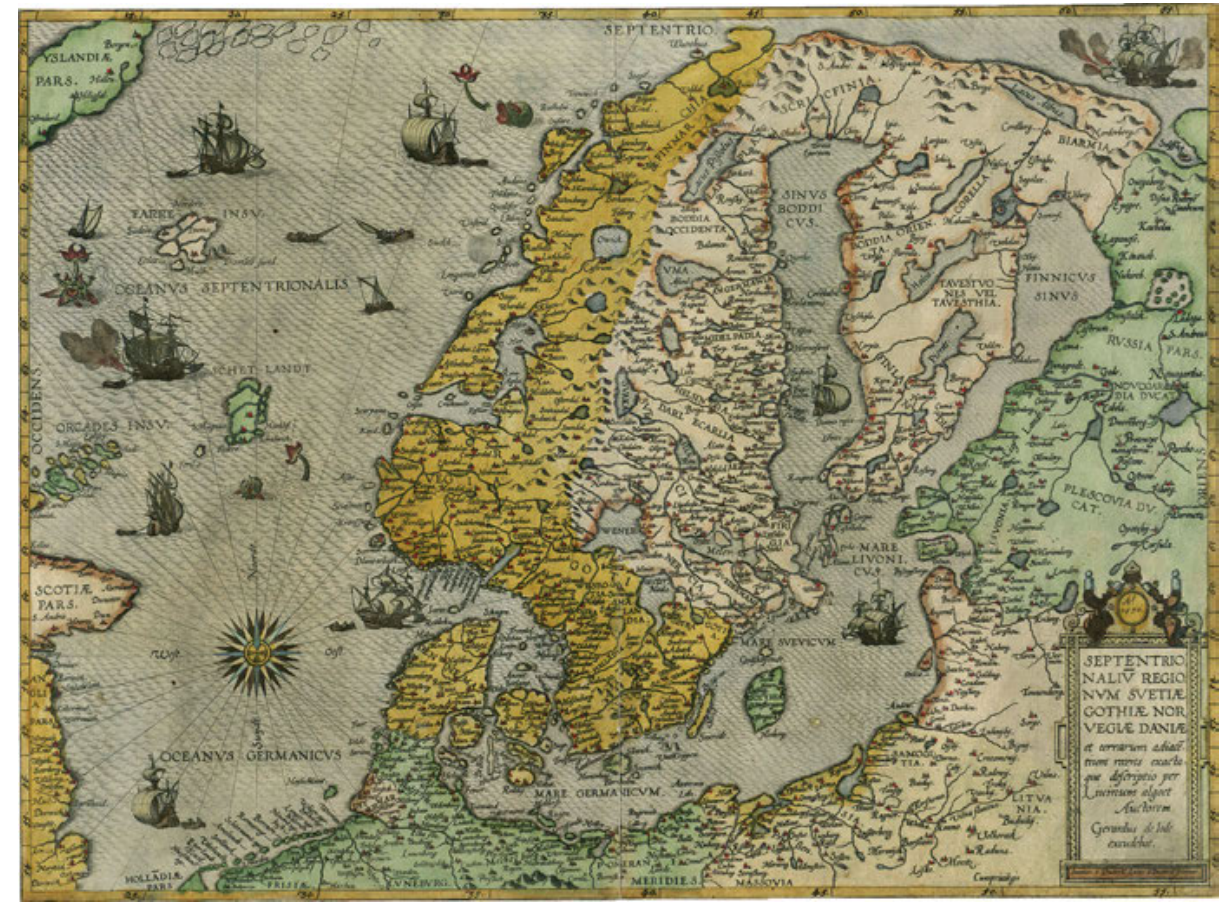

Fig. 5.0: Map of the Scandinavian countries. Septentrionaliv regionvm Svetiæ Gothiæ Norvegiæ Daniæ et terrarum adiacetium recens exactaque descriptio, Jode, G. de Algoet, Lievin, 1570. 